Article

\title{
Insertion of Photovoltaic Solar Systems in Technological Education Institutions in Brazil: Teacher Perceptions Concerning Contributions towards Sustainable Development
}

\author{
Maurisete Fernando Ferreira ${ }^{1,2, *}$, Marcos Aurélio Vasconcelos Freitas ${ }^{2,3}$, \\ Neilton Fidelis da Silva ${ }^{1,2,3}$, Antonia Francimar da Silva ${ }^{1}$ and Luciana Rocha Leal da Paz ${ }^{4}$ \\ 1 Institute of Education, Science and Technology (IFRN), Natal 59015-000, Brazil; \\ neilton@ivig.coppe.ufri.br (N.F.d.S.); antonia.silva@ifrn.edu.br (A.F.d.S.) \\ 2 Energy Planning Program (PPE/UFRJ), Rio de Janeiro 21941-914, Brazil; mfreitas@ivig.coppe.ufrj.br \\ 3 International Virtual Institute of Global Changes (IVIG/COPPE), Rio de Janeiro 21941-909, Brazil \\ 4 Electric Energy Research Center (CEPEL), Rio de Janeiro 21944-970, Brazil; lrocha@cepel.br \\ * Correspondence: maurisete.ferreira@ifrn.edu.br; Tel.: +55-84-999504069
}

Received: 16 January 2020; Accepted: 31 January 2020; Published: 11 February 2020

\begin{abstract}
Teaching spaces are seen as institutions presenting relevant power to promote sustainability. Thus, in addition to knowledge (re)producers, they must also assume ethical obligations to incorporate daily sustainability-oriented actions. In this context, this study evaluates faculty perceptions regarding contributions to the teaching-learning process and the diffusion of a pedagogical practice adhering to sustainability assumptions, arising from the insertion of photovoltaic solar systems in educational institutions. A study was conducted at the Rio Grande do Norte Federal Institute of Education Science and Technology, with 2.2 photovoltaic MWp distributed throughout its 21 campuses. This study investigated teacher knowledge and attitudes towards renewable energy sources in their school practice, as a way of understanding these issues and presenting propositions that will strengthen their role in daily school life. Teachers are aware of the importance of these sources, but their knowledge does not form links with their practice. Thus, the necessary connections to promote sustainability from the existence of institutional photovoltaic systems were proven insufficient. They did not support the concept, nor the adoption of pedagogical practices linked to this technology. In addition, teacher inability to bring knowledge related to renewable energies to the classroom and link them to daily student lives was also noted. The adoption of renewable energy to promote a sustainability culture demands the formation of teacher knowledge and attitudes, and this training must follow a continuous path.
\end{abstract}

Keywords: renewable energy; sustainability; teaching-learning; photovoltaic; teachers; school; education; sustainable development

\section{Introduction}

Formal teaching spaces, in particular, are seen as institutions with relevant potential in promoting sustainable development. Thus, they assume ethical obligations to systematically incorporate daily sustainability actions and pedagogical practices in their intervention and operations networks, and should not act only as knowledge reproducers. In this context, United Nations Environment Programme (UNEP) implemented different programs around the world with education for sustainability as a guide for changes that incorporates issues of environmental ethics and sustainable development in teaching and research [1]. According to López-Alcarria [2] these spaces must be committed to ethically 
educating responsible citizens through sustainability, thus preparing them for the working world, which responds rapidly to the constant changes in our ever-changing society.

In this context, the role of education in the pursuit of sustainable development has been debated since its first mention in the Agenda 21, more specifically in Chapter 36, which deals with the Promotion of Teaching, Awareness and Training. [3]. This document suggests that education aimed at promoting sustainable development should be integrated into all disciplines and should employ formal and informal methods and effective means of communication, thus enabling the establishment of a process in which human beings and societies can develop their potential in an integrated manner.

It covers the transmission of knowledge and values in early childhood, scientific, vocational education, as well as in training and informal education. Accordingly, each step should display its own peculiarity according to the age and education level of the target audience [4].

Regardless of the ideas present in the formation of knowledge and methodological paths applied to the objectives set for education, what is historically observed is that this is the most appropriate way to lead to society transformation. Freire [5] argues that education should be based on the ethical pedagogy of respect for others and the learner's autonomy, and should be able to form historical, transforming and ethical subjects who refuse to reproduce individualism [6]. The educational formation space has the prerogative of being able to generate knowledge and thoughts oriented to criticism of the established rules, empowering the set of actors that make up the school to address collective interest themes that structure and develop solutions oriented towards the ordering of a sustainable society $[4,7]$.

The complexity of the sustainability theme demands and should bring about changes in individual, organization and society behavior. Today's technical scientific world, where production and consumption dictate the urgent ways of dealing with resources available in nature, privileges capital over social and environmental resources [8]. The way in which a significant number of social actors perceive the environment and formulate common sense based on everyday perception defines a statistically dominant way of understanding the sustainability theme and the way to act to promote this theme. Such a majorly action-reaction format, based on the socially created perception of things, passes by and is intensified or rejected by the school, thus being inexorably linked to the teaching-learning process.

A sustainable society is viable when it overcomes a utilitarian and simplistic view that guides the modern civilizing process, and adopts a broad reading in the relations between human beings and nature, where attitudinal changes can materialize: humans sees themselves as part of a species, dialoguing with mutual responsibility, for each and every one, for the place they inhabit, with regard to the alteration and vulnerability of each being [6]. In these terms, Sachs [9] sees "sustainability as a balanced economic, social, political, cultural and environmental model capable of meeting the needs of present generations without removing the possibility of future generations also meeting their own needs", and thus advocates transformative education in the form idealized by Freire [5] as a progressive, curious and critical educational practice that, being dissatisfied and unworthy, is capable of forming solidary people, with ethical values and builders of knowledge inserted in social action. Thus, Freire [5] states that:

"[ ... ] every liberating educational practice, valuing the exercise of the will of decision, of resistance, of choice; the role of emotions, feelings, desires, limits; the importance of consciousness in history, the ethical sense of human presence in the world, the understanding of history as a possibility, never as a determination, is substantively hopeful and, therefore, provocative of hope."

Accordingly, education displays a direct relationship with social, economic and sustainable development. Thus, the school assumes an extremely important role and can be considered a protagonist for transformations, since the school environment provides children and young people the conceptions of opinion, conduct, and even part of the values that can be acquired during this maturity phase.

Educating for sustainability should, then, point towards building a set of skills and competencies that stimulate the social engagement of those who make up the set of actors that, in turn, make up 
the teaching-learning environment. López-Alcarria et al. [2] argue that these competences should be linked to conceptual, methodological and socio-affective aspects, involving an innovative approach, integrating knowledge to be acquired with a form of teaching that uses ethical criteria of social justice, equity, solidarity and respect for the environment $[10,11]$.

The construction of sustainability should have education as its central axis, given that the form of education we have today helped create the problems that shape the sustainability "crisis". For Morin [12], the traditional mode of knowledge transmission, and as a consequence of teaching, leads us to metaphorically separate objects from their environment; knowledge is placed in drawers in a fragmented way, separated and without apparent connection, disjointed and compartmentalized in disciplines and not bringing to surface what is part of the same fabric. At the same time, we live in a globalized world presenting a multidimensional, transnational and planetary reality, and problems are increasingly transversal, polydisciplinary and transdisciplinary, which imposes, according to Morin [12] a complex and emergency "reform" of the thinking required to materialize sustainability.

According to this paradigm, sustainable development oriented education (SDOE) shapes the core competencies to enable students to develop harmoniously, act actively in the present, make responsible decisions and support the sustainable development of society in the future [6,9]. Thus, sustainable development should enable natural systems to be sustained by allowing economies and societies to achieve the goals of human development. In other words, sustainable development means that current actions should not undermine the ability of future generations to meet their needs $[13,14]$. SDOE aims to "empower and equip present and future generations to meet their needs, using a balanced and integrated approach to the economic, social and environmental dimensions" [15]. In this sense, education must reinforce the concept of sustainability, which advocates that the use of natural resources be made to ensure their availability also for future generations. From this perspective, knowledge of the potential benefits and harnessing of renewable energy sources may be an alternative for humanity to adopt a sustainable path of development.

In Brazil, the shaping of an institutional environment conducive to sustainability in the 2010s [16] emphasized the adoption of actions that promote the generation of electricity from renewable sources and disseminate the assumptions of sustainability in teaching-learning spaces.

Thus, the Federal Government, through the Ministry of Education, formulated a public policy to encourage the adoption of photovoltaic power plants in its 82 teaching units: the IF Solar Project. When accomplished, about $5.5 \mathrm{GW}$ of photovoltaic power plants is expected to be installed on the 644 campuses of the Federal Network. For the approval of the budget allocation to the IF Solar Project, the Federal Government justified the viability because it: (i) promotes the reduction of electricity costs in the institutions; (ii) becomes a disseminating agent of the assumptions of sustainability and its benefits, by incorporating the characteristics of the adopted technology that allows integrating the knowledge and routines experienced in photovoltaic generation units to teaching practice.

In this context, this study aims to evaluate teacher perceptions regarding the presence and influence of the adoption of the photovoltaic solar systems in the pedagogical practice at school, in the teaching-learning process and in the diffusion of the premises of sustainable development in the teaching spaces. To this end, a survey was used with the faculty of the Federal Institute of Education, Science and Technology of Rio Grande do Norte (IFRN) to allow the direct interrogation of these actors, in order to map their knowledge and attitudes towards renewable technologies in their teaching practice as a way to understand them and, from there, to evaluate the effectiveness of the public policy of insertion of solar systems. This will enable the study to present intervention propositions that will strengthen the role of these systems in daily school life, thus contributing to the formation of environmentally committed generations aware of the role of energy in society. 


\section{The Federal Professional, Scientific and Technological Education Network-IFRN}

\subsection{The Specificities of the Federal Network and the Role of the Teacher}

The Federal Professional, Scientific and Technological Education Network (Federal Network) is part of the federal education system linked to the Ministry of Education. The Federal Network is composed by a set of institutions, namely:

I Federal Institutes of Education, Science and Technology (Federal Institutes);

II Federal Technological University (UTF);

III Federal Centers for Technological Education (CEFET) and Minas Gerais;

IV Technical Schools linked to Federal Universities.

The Federal Network, which has administrative, patrimonial, financial, didactic-pedagogical and disciplinary autonomy, is configured as an important structure for the Brazilian student to have access to scientific and technological achievements, within the assumptions of a comprehensive quality education with a social reference. Present throughout Brazilian territory, the Federal Network has the social function of qualifying professionals for the various sectors of the Brazilian economy, conducting research and developing new processes, products and services in collaboration with the productive sector.

Currently, the Federal Network consists of 38 Federal Institutes, 2 Federal Centers for Technological Education (CEFET), 1 Federal Technological University (UTF) and 22 Technical Schools. Considering the respective campuses associated with these federal institutions, a total of 644 units are distributed among the 27 federal Brazilian units, offering: (i) qualification courses at the basic level; (ii) technical courses at the high school level; (iii) degrees at the technology, bachelor, master's and doctorate levels.

\subsubsection{Specificities of the Federal Network and the Role of the Teacher}

Educational work, at any level, demands a set of requirements, especially when it comes to vocational and technological education. A specificity is noted as, in addition to propaedeutic training, teachers should master content, work techniques and learning methodologies that are in tune with the reality of the work world, the appropriation of technologies and national and regional development. Thus, professional education subjects are encouraged to put themselves as subjects of reflection and research, open to collective work and cooperative critical action, in order to truly work on technoscience and promote sustainability.

This means overcoming dichotomies between science/technology and theory/practice, overcoming the compartmentalized vision of knowledge, and the deeper appropriation of knowledge, now at an ever-faster construction and deconstruction pace. This dealing with rapidly overcoming technoscience brings within the knowledge construction process the need to definitively install research as an educational principle, in addition to the scientific principle.

The Federal Institutes, with a unique organization and management proposal, are inseparable from national education. In their autonomy, they reflect the reality in which they dialogue, regionally and locally, considered in tune with the global reality, from a sustainable development perspective [17].

\subsubsection{Thematic Committee on Professional Training in Renewable Energy and Energy Efficiency}

Within the Secretariat of Professional and Technological Education of the Ministry of Education, the Thematic Committee on Vocational Training in Renewable Energy and Energy Efficiency was created in 2015 to promote sustainable development in line with the expansion of vocational training and human resources training in renewable energy and energy efficiency. This committee has among its objectives and activities the following [17]:

- To promote dialogues with the productive sector linked to the renewable energy market;

- To promote renewable energy; 
- To develop teaching materials related to renewable energy and sustainable development;

- To train Federal Institute teachers for new content related to renewable energy, energy efficiency and sustainability;

- To assess and qualify effectiveness of implemented actions.

\subsubsection{IF Solar Project}

Solar based on the guidelines of the Thematic Committee on Vocational Training in Renewable Energy and Energy Efficiency. The objective was to implement photovoltaic plants for the generation of electricity in Federal Network units from Minas Gerais.

According to South of Minas Federal Institute of Education, Science and Technology (IFSULDEMINAS) [18], seeking alternative energy generation sources has been a difficulty for most institutions, hence the motivation for an innovative and pioneering project that combines sustainability, financial resource savings and interventions in the teaching-learning process that lead the science concerning the benefits of harnessing renewable sources, especially photovoltaic solar energy, to the different institutional actors.

The IF Solar Project includes the installation of photovoltaic solar plants on 82 campuses in different federal institutes. In all, 20,172 photovoltaic panels comprising $265 \mathrm{Wp}$ each, totaling $5470 \mathrm{MWp}$ were installed. Each installed plant displays the potential to generate, on average, $105 \mathrm{MWh}$ per year, emitting about 30 tons less of carbon dioxide $\left(\mathrm{CO}_{2}\right)$ per year to the environment. The investment value, when completed, could reach US\$11.4 million [18].

IFSULDEMINAS's internal experience indicates that the amounts available for photovoltaic system acquisition totaled US\$137 thousand each, installed on campuses roof and parking lots. The financial valuations indicate an annual IFSULDEMINAS savings of US $\$ 175$ thousand and the expected investment return after its implementation is four years.

At the national level, the IF Solar Project contemplates the bidding to attend the 82 Federal Technological Education Network units, totaling an approximate investment of US\$11.9 million. Among the institutions benefiting from the project, Baiano Federal Institute of Education, Science and Technology (IFBAIANO) estimates that it will save $40 \%$ of their annual electricity consumption, and IFSULDEMINAS expects savings of US $\$ 7,900$ per month. In total, the savings for all the institutes that joined the project are estimated at US\$2 million per year [18].

\subsection{The Rio Grande do Norte Federal Institute of Education, Science and Technology (IFRN)}

\subsubsection{Social Function}

Structured in 20 campuses distributed throughout the state of Rio Grande do Norte, the Rio Grande do Norte Federal Institute of Education, Science and Technology (IFRN) has the social function of promoting scientific-technological-humanistic education aiming at the integral formation of the professional-citizen, reflexive-critical, technically and ethically competent and effectively committed to social, political and cultural transformations through initial and continuing formation, high school technical vocational education, technological professional undergraduate and postgraduate education, and teacher training. Figure 1 displays the location of the 20 IFRN units distributed throughout Rio Grande do Norte. 


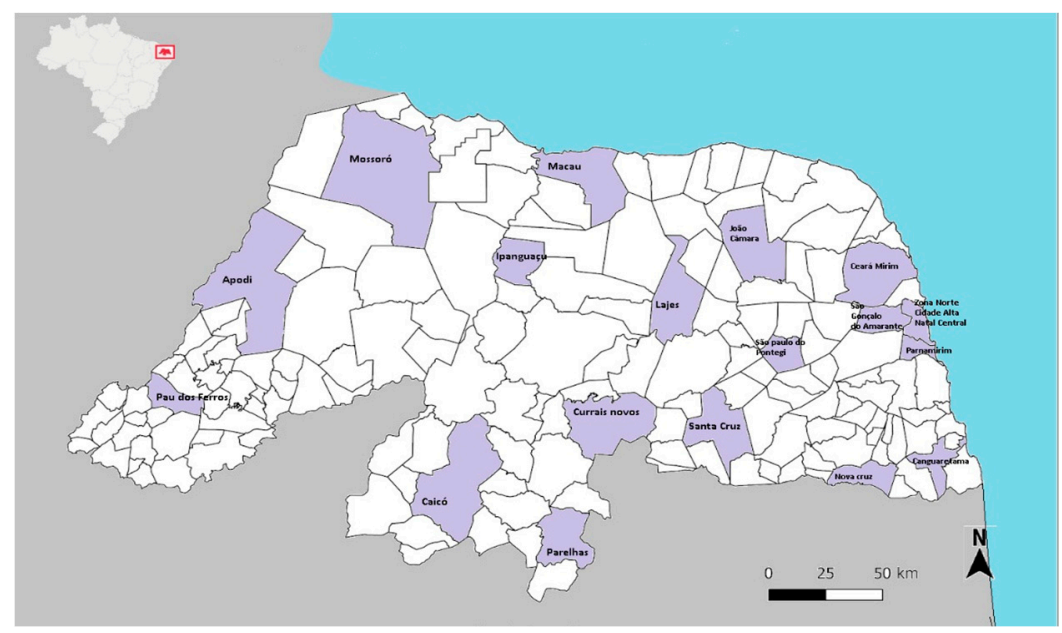

Figure 1. Location of the 20 Federal Institute of Education, Science and Technology of Rio Grande do Norte (IFRN) units distributed throughout Rio Grande do Norte. Source: [19].

\subsubsection{Academic Structure}

The IFRN currently has 1596 teachers, to serve about 26,000 students, distributed throughout all levels of education. Its structure offers 109 middle, undergraduate and postgraduate courses in the areas of Control and Industrial Processes; Educational and Social Development; Management and Business; Information and Communication; Infrastructure; Food Production; Cultural Production and Design; Tourism, Hospitality and Leisure; Industrial Production and Natural Resources and Energy. It also acts in the initial and continuing formation of teachers, especially in areas where teacher shortage is greatest, such as Mathematics, Chemistry, Biology and Physics. Figure 2 presents the enrollment distribution according to educational level.

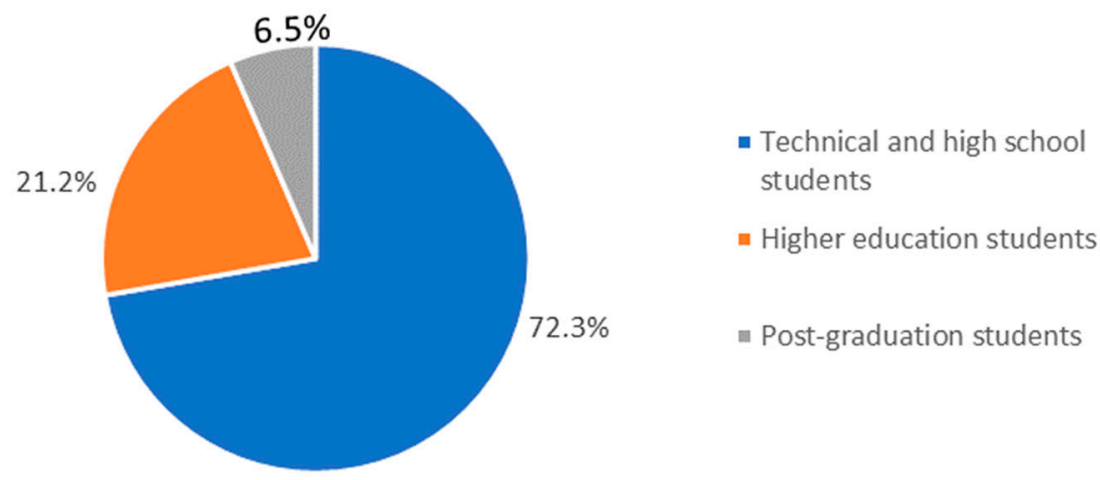

Figure 2. Student distribution by course at IFRN in 2018. Source: [19].

\subsection{IFRN Solar Project}

IFRN participates in the IF Solar Project with its own version, called the IFRN Solar Project, which already totals an installed capacity of $2139.78 \mathrm{KWp}$ distributed throughout 21 grid-connected systems.

The installed systems count on the energy compensation provided in Normative Resolution 482, of 17 April, 2012, stipulated by the National Electricity Agency [20]. This resolution allows consumers to connect their own electricity-generating system from renewable sources (hydraulic, solar, wind, biomass or cogeneration), parallel to concessionaire distribution networks, and to offset the energy generated by this network.

Table 1 summarizes the main information regarding the photovoltaic systems already installed at IFRN. This indicates that the project made use of a public funding consisting of US\$4.9 million. 
Table 1. Technical Information on the photovoltaic plants already installed in the IFRN Solar Project. Source: [21].

\begin{tabular}{|c|c|c|c|c|}
\hline Unit & Inauguration & $\begin{array}{l}\text { Investment } \\
\text { (US\$) }\end{array}$ & $\begin{array}{c}\text { Type of } \\
\text { Installation }\end{array}$ & $\begin{array}{c}\text { Installed Power } \\
(\mathbf{k W p})\end{array}$ \\
\hline \multirow{2}{*}{ Reitoria } & $12 / 2013$ & $97,852.76$ & Roof & 56.40 \\
\hline & $11 / 2017$ & $65,812.69$ & Roof & 27.83 \\
\hline Ceará Mirim & 03/2014 & $198,753.89$ & Roof & 112.80 \\
\hline São Paulo do Potengi & 04/2014 & $206,472.49$ & Roof & 112.80 \\
\hline Canguaretama & 02/2015 & $206,472.49$ & Ground & 112.80 \\
\hline Currais Novos & 05/2015 & $189,504.37$ & Ground & 112.80 \\
\hline Parelhas & $08 / 2015$ & $82,901.55$ & Roof & 50.00 \\
\hline São Gonçalo do Amarante & $11 / 2015$ & $124,261.08$ & Parking lot & 56.35 \\
\hline \multirow{2}{*}{ Natal Central } & $01 / 2016$ & $144,343.89$ & Roof & 112.80 \\
\hline & $01 / 2016$ & $130,147.06$ & Roof & 84.53 \\
\hline Pau dos Ferros & 06/2016 & $199,739.58$ & Roof & 114.40 \\
\hline Caicó & $08 / 2016$ & $280,277.78$ & Parking lot & 114.40 \\
\hline João Câmara & $09 / 2016$ & $271,967.65$ & Parking lot & 114.40 \\
\hline Lajes & $12 / 2016$ & $86,486.49$ & Roof & 50.00 \\
\hline \multirow{2}{*}{ Mossoró } & 05/2017 & $199,853.21$ & Roof & 83.48 \\
\hline & $10 / 2017$ & $133,235.47$ & Roof & 55.65 \\
\hline \multirow{2}{*}{ Santa Cruz } & 04/2017 & $210,812.90$ & Roof & 84.80 \\
\hline & $11 / 2017$ & $66,617.74$ & Roof & 27.83 \\
\hline Natal Cidade Alta & $10 / 2017$ & $282,870.66$ & Parking lot & 83.48 \\
\hline Parnamirim & $10 / 2017$ & $282,870,66$ & Parking lot & 83.48 \\
\hline \multirow{2}{*}{ Natal Zona Norte } & $10 / 2017$ & $199,243.90$ & Roof & 83.48 \\
\hline & $10 / 2017$ & $66,414,63$ & Roof & 27.83 \\
\hline Nova Cruz & $11 / 2017$ & $283,765.82$ & Parking lot & 88.20 \\
\hline Apodi & $11 / 2017$ & $270,090.36$ & Parking lot & 88.20 \\
\hline Ipanguaçu & $12 / 2017$ & $357,964.07$ & Parking lot & 117.60 \\
\hline Macau & $12 / 2017$ & $268,473.05$ & Parking lot & 83.48 \\
\hline
\end{tabular}

Source: Prepared by the authors.

Concerning 2018, with 21 installed systems, the photovoltaic generation units provided $2,170,757 \mathrm{KWh}, 24 \%$ of the electricity demanded by the IFRN, which reduced electricity costs by about US $\$ 337$ thousand dollars. The projected return of this investment is 13 years, considering that the useful life of the panels reaches 25 years, and that maintenance will be restricted to simple panel cleaning and electrical connections maintenance [21]. In this same period, Constantino [22] shows that avoided $\mathrm{CO}_{2}$ emissions totaled around 10 tons.

\subsubsection{IFRN Solar Objectives}

The IFRN Solar Project, in line with the Federal Government, aims to save public financial resources by reducing electricity costs. The IFRN Solar Project also provides the extension of the use of the generation units as laboratories for teachers and students to disseminate, in the teaching process, the social and environmental values attributed to the use of renewable sources. It hopes to expand knowledge, research and innovation in this area, both on the technical and socio-environmental bias and thus promote and disseminate actions aimed at promoting sustainability in teaching spaces.

Regarding the sustainable development benefits of adopting photovoltaic solar energy and energy efficiency, it is necessary that such knowledge, and consequently its benefits, be incorporated into the educational process, whether formal or informal. Education is, therefore, paramount to the promotion of sustainability-aimed actions. The recognition of certain limits imposed by the environment or by our duties to the present and future generation are processes through which the individual and the community build social values, knowledge, skills, attitudes and competences focused on ways of harnessing natural resources.

The National Education Council Resolution CNE/98 [23], by instituting the National Curriculum High School Guidelines, organizes the areas of knowledge and guides education, sustainability and 
solidarity promotion, all citizenship attributes. The objectives of teaching in each scientific and mathematical knowledge area combine the development of contextualized practical knowledge and sustainability. This is knowledge that responds to the needs of contemporary life and also to the development of broader and more abstract knowledge capable of expanding the general culture and worldview.

The growing appreciation of knowledge and the ability to innovate requires the ability to learn continuously from citizens, seeking a general education that promotes sustainability and not only specific training. Learning from natural sciences, geography and mathematics aims to promote skills and abilities that will serve as exercises, interventions and practical judgments. In other words, this means understanding theoretical procedures, obtaining and analyzing information, assessing the risks and benefits of technology adoption processes, and the broad meaning of citizenship and sustainability.

\subsubsection{Adherence to Goals}

The analysis of the IFRN Solar Project implementation, albeit in a poorly structured way based on daily perceptions, indicates acceptance and a positive evaluation by the segments that make up the institution, comprising teachers, students, servers and the user community. This acceptance, lacking an experience-based and/or method-based assessment, seems to reflect the widespread common sense in the media about the benefits of renewable energy sources in the face of environmental issues and the risks to humanity arising from today's environmental problems, faced at local, regional and global levels. Thus, concerning public opinion, the sustainability benefits arising from the adoption of the IFRN Solar project are undisputed.

In these terms, it is imperative that IF Solar expand its "rational use" space by overcoming the opportunity reading through the unique $\mathrm{kWh}$ optics avoided due to the useful life of the installed systems. It is then necessary to appropriate the segments that make up the knowledge and skill institution provided by the use of photovoltaic systems in space and in teaching practices.

Teachers are responsible for incorporating such knowledge and skills in their practice, either through the inclusion of the photovoltaic solar energy's own contents in curriculum guidelines and/or teaching, research and extension activities, or as an indispensable act of citizenship for any subject who makes use of natural resources. The student body must experience, understand and indicate materiality and active belonging to the systems installed in its teaching units, bringing this experience to the daily life of the classroom. This daily life, in turn, should be guided by the faculty when incorporating the knowledge linked to photovoltaic systems, connected to different areas of knowledge, in the teaching-learning process.

The challenge posed to the IFRN Solar project, in its aim to promote sustainability, demands actions that measure the perceptions of the different actors that form the educational space regarding the project's sustainability contributions. From this diagnosis, specific actions directed to each segment (teachers, students, servants and community) can be structured as part of the educational process, in order to promote teaching and training methods oriented towards sustainable development, not only as code and norm generators and reproducers, but systematically incorporating sustainability-oriented actions in their different dimensions.

Thus, there is a need to add to the teaching practice experiences that dialogue with other sources and methods of access and transmission of knowledge, so that the student can, when finding and obtaining the information necessary for their formation. In this search, an example is Poder's experience of Copenhagen International School [24], which, by investing in a photovoltaic generation unit designed to meet half of the institution's demand, projects the school as a center that promotes sustainability and makes use of a pedagogical strategy. It contributes to education of its students for a sustainable global future. The installed photovoltaic system is present in the daily student experience. All generated numbers and related knowledge are part of the student's formal education and are distributed to them daily. Students and teachers monitor daily energy production and use their data in the disciplines 
of physics, mathematics, and other areas of knowledge. This action gives teachers and students' awareness and knowledge about renewable energy and its importance in promoting sustainability.

\section{Methodology}

Due to the object of the research, the methodological choice was to use the applied research strategy, in a quantitative approach of the problem with a description of a given population or phenomenon. It used the procedure described in literature as "survey", which allows direct questioning of the actors by questionnaire, and after that quantitative analysis to obtain the conclusions corresponding to the collected data [25]. Thus, the teachers were given a voice about the challenges they face in relation to their pedagogical practice for the inclusion of the subject "sustainability" in curricula and school daily life in an institutional way, considering the public policy to encourage the adoption of photovoltaic solar systems in teaching spaces.

Therefore, a questionnaire was used to obtain information and collect data that would not be possible only through a bibliographic and documentary research, thus enabling the capture of elements that reveal information determined by experience and individual points of view. For Vilelas [26] this tool synthesizes in itself all the previous research work, summarizes the approximations of the theoretical framework to the phenomenon to be studied and, therefore, the applied variables or concepts. So, the author states: "It is by means of an adequate construction of the data collection instruments that the research then reaches the necessary correspondence between theory and facts" [26].

The questionnaire was designed to obtain information on the technological, environmental and educational dimensions, which may be appropriate for the insertion of photovoltaic solar systems in educational institutions. Thus, the stage of the faculty's knowledge concerning: (i) renewable energy sources and their conversion technologies; (ii) sustainable development; (iii) photovoltaic solar plants installed on campuses; and (iv) the incorporation of relevant knowledge to the IF Solar Project in the teaching-learning, internalization, publicization and appropriation processes as to its contribution to sustainable development were diagnosed. Therefore, the questionnaire was structured according to Morgado [27]:

(i) Closed or Dichotomous Questions: Restricted questions in which the interviewee is offered fixed alternatives with only two answer options, either bipolar or dichotomous, such as: yes/no; agree/disagree; like/don't like. In some cases, a third alternative is offered, indicating ignorance or lack of opinion on the subject;

(ii) Multiple choice questions: Closed-ended questions that offer a group of possible answers, where the respondent elects one of the alternatives, or a certain allowable number of answer options;

(iii) Scored Answer Questions: Multiple choice questions, where options are intended to capture the intensity of respondent responses, given by a frequency level or hierarchy in which they are enumerated.

Thus, the research carried out in 2018 included the elaboration of a questionnaire applied to 310 teachers for the diagnosis of different teacher perceptions and attitudes regarding the inclusion of renewable energy sources in educational institutions and/or their possible interactions, adjustments or reforms in the teaching-learning process considering different regions and levels of education. In this process, different IFRN campuses installed throughout the state of Rio Grande do Norte were considered.

\subsection{Sample Determination}

The population that constitutes the research universe consists of IFRN teachers active in the 2018 school year, totaling 1596 teachers distributed among 20 campuses that make up the institution [19]. Teachers from various areas of knowledge participated in the study, from both propaedeutic and professional areas. The sample is stratified by campuses, as there is homogeneity within each campus and heterogeneity among campuses. 
Thus, the sample elements were chosen in a random and statistically representative way using a technique from the probabilistic sample family, which consists in dividing the total population into different subgroups so that the individual can be part of only one stratum. The population was divided into 20 strata, comprising campuses that make up the IFRN. The teacher samples from each of these strata were proportional to the number of teachers each campus has in relation to the total teacher population. Equation (1) was used to determine the sample, considering a sampling error of $5 \%$ and a confidence level of $95 \%$, as follows: [28].

$$
n=\frac{z_{\alpha / 2}^{2}}{e^{2}+\frac{z_{\alpha / 2}^{2}}{N}} S^{2}=\frac{n_{0}}{1+\frac{n_{0}}{N}}
$$

where

$$
n_{0}=\frac{1.96^{2}}{4 e^{2}}
$$

For large populations, $\mathrm{S} 2 \sim \mathrm{p}(1-p)$, where $p$ is the probability of the event reaching its maximum value when $p=0.5$, which is then used in the following calculation.

$$
n_{0}=\frac{1.96^{2}}{4 e^{2}}
$$

$z$-Standardized normal variable associated with confidence level. The confidence index used is $95 \% \mathrm{z}$ with a maximum width of $2 \mathrm{e}$, where $\mathrm{e}=5 \%$ (sampling error), or 0.05 .

Since $N=1596$, the teacher population, sample $n=310$ was determined using Equation (1). Once the sample was established, samples from each campus were determined by a direct calculation. Table 2 presents the total questionnaire distribution applied to teachers from each IFRN unit.

Table 2. Sample distribution per campus.

\begin{tabular}{ccc}
\hline Campus & $\begin{array}{c}\text { Teacher Population on } \\
\text { Each Campus } \mathbf{( N}_{\mathbf{h}} \mathbf{)}\end{array}$ & $\begin{array}{c}\text { Sample Teachers from } \\
\text { Each Campus } \mathbf{( n}_{\mathbf{h}} \mathbf{)}\end{array}$ \\
\hline Apodi & 65 & 14 \\
Caicó & 68 & 12 \\
Canguaretama & 64 & 13 \\
Ceará Mirim & 63 & 15 \\
Currais Novos & 70 & 16 \\
Ipanguaçu & 70 & 12 \\
João Câmara & 65 & 11 \\
Lajes & 30 & 9 \\
Macau & 72 & 15 \\
Mossoró & 108 & 19 \\
Natal Central & 340 & 51 \\
Natal Cidade Alta & 73 & 12 \\
Natal Zona Norte & 68 & 15 \\
Nova Cruz & 71 & 14 \\
Parelhas & 31 & 5 \\
Parnamirim & 68 & 14 \\
Pau Dos Ferros & 73 & 12 \\
São Paulo do Potengi & 64 & 19 \\
Santa Cruz & 67 & 18 \\
São Gonçalo & 66 & 14 \\
Total & $\mathbf{N} \mathbf{1 5 9 6}$ & $\mathbf{3 1 0}$ \\
\hline
\end{tabular}

Source: Prepared by the authors. 
The chi-square test $(\chi 2)$ was applied to verify the existence of statistically significant differences regarding the perceptions and attitudes of teachers from different areas of knowledge, regarding the inclusion of renewable energy sources in educational institutions and/or their possible interactions, and regarding the data obtained when these groups were gathered in one group (IFRN teachers).

\subsection{Pretests and Questionnaire Application}

According to Lakatos [29] a pretest should be conducted on a small sample of respondents to identify and eliminate potential problems. The pretests were conducted in May 2018 by applying 30 questionnaires, $10 \%$ of the sample, through face-to-face interviews assisted by a team researcher, as a way to follow up interviewee reactions, attitudes and possible embarrassment. During the pretest stage overlapping questions, ambiguous and/or unclear questions could be detected. The pretest enabled coding and problem detection analysis and, consequently, questionnaire adjustment in order to obtain the desired information.

Random pretest participant selection ensured gender, area of expertise, and faculty performance parity. Teachers who participated in the pretest were excluded from the sample upon final questionnaire application.

A team of 15 collaborators was instructed to meet the following criteria for questionnaire application:

- Informants should answer the questionnaires in ink and in front of the applicator;

- Informants could make any queries;

- Time was not limited, so the informant could use as much time as he or she thought is necessary;

- After replying, the informant should immediately submit the questionnaire to the applicator;

- The completed questionnaires were kept in an envelope and delivered to the main researcher;

- Each applicator was instructed to apply as many or more questionnaires as determined in Table 3, according to each campus;

- Informants were randomly selected by the applicator.

\section{Results and Discussion}

\subsection{Teachers Profile}

Of a total of 310 questionnaires applied to faculty across the 20 assessed campuses of IFRN, $73 \%$ were answered by men and $27 \%$ by women. These percentages are well representative of the teaching population in the Institute, which is distributed as $67 \%$ male teachers and $33 \%$ female teachers. Despite the importance of the successful experience of teachers' working time in the classroom, age and public service time were not evaluated, as well as no gender approach, since the main aim of the study is to measure how teachers perceive and/or incorporate the knowledge and attitudes arising from the presence of photovoltaic solar systems in the teaching-learning process in teaching spaces. Teacher areas of knowledge and practice were identified, since these may, directly or indirectly, be based on pedagogical practice and close relations with knowledge related to renewable energy, its resources, conversion technologies and sustainability.

Regarding the teachers who answered the survey, 15.7\% teach in code, language and their technologies area, while $18.3 \%$ are from the humanities and technologies field, $36.6 \%$ are from the natural sciences, mathematics and their technologies area and $29.4 \%$ are from the technology area. Accounting for the percentages distributed by knowledge area, a balanced distribution between the areas is evident, which allows a kaleidoscopic view of the research. Teachers acting in the natural sciences, mathematics and their technologies, such as chemical physics, biology and mathematics, have their training and classroom daily life based on a greater possibility to dialogue with knowledge related to renewable energies and sustainability, according to the contents covered in the subjects. 
For technology teachers, this possibility is much more expanded, since knowledge about renewable energy can compose the university education curriculum, as, for example, in engineering.

\subsection{Teachers Declared Level of Knowledge on Different Renewable Energy Sources}

Regarding the questionnaire, three questions were designed to assess how teachers self-described their knowledge on renewable energy. In these terms, Zyadin et al. [30] consider that it is not a common practice in academia to ask teachers how they rate their knowledge of a particular subject that may be linked to their pedagogical practice. However, this approach was necessary to compare measured teachers' knowledge level based on their own assessments. This question does not aim at verifying any level of knowledge, but the presence of sustainability as a theme in teachers' practice. It was investigated the origin of such knowledge and, thus, could be evaluated whether the IFRN Solar Project was part of the teachers' knowledge. This specific contribution from the IFRN Solar Project should be expected once one of its objectives is to incorporate knowledge inherent to renewable energy sources technology to teachers' practice.

Concerning answers on renewable energy, $99.7 \%$ of the interviewees said they did possess knowledge in the area. Figure 3 presents the IFRN percentages concerning faculty knowledge on renewable energy. The teachers did in fact reveal knowledge on renewable energy, although higher concerning wind and photovoltaic sources compared to other sources.

Borg et al. [31] states that teachers from different fields build and evaluate their knowledge on a particular subject differently (i.e., are influenced by their own traditions in the subject). Thus, teaching knowledge level was stratified by activity area, to capture such differences.

When stratified by knowledge area (Figures 4-7), natural sciences area teachers reported having knowledge about renewable sources, as well as their different sources, followed by technology, humanities and, finally, codes and languages. This was expected, since content linked to renewable sources is primarily viewed as technological and mathematical, while the socioeconomic and environmental approach seems to be seen as belonging to a secondary plan adhering to the social sciences.

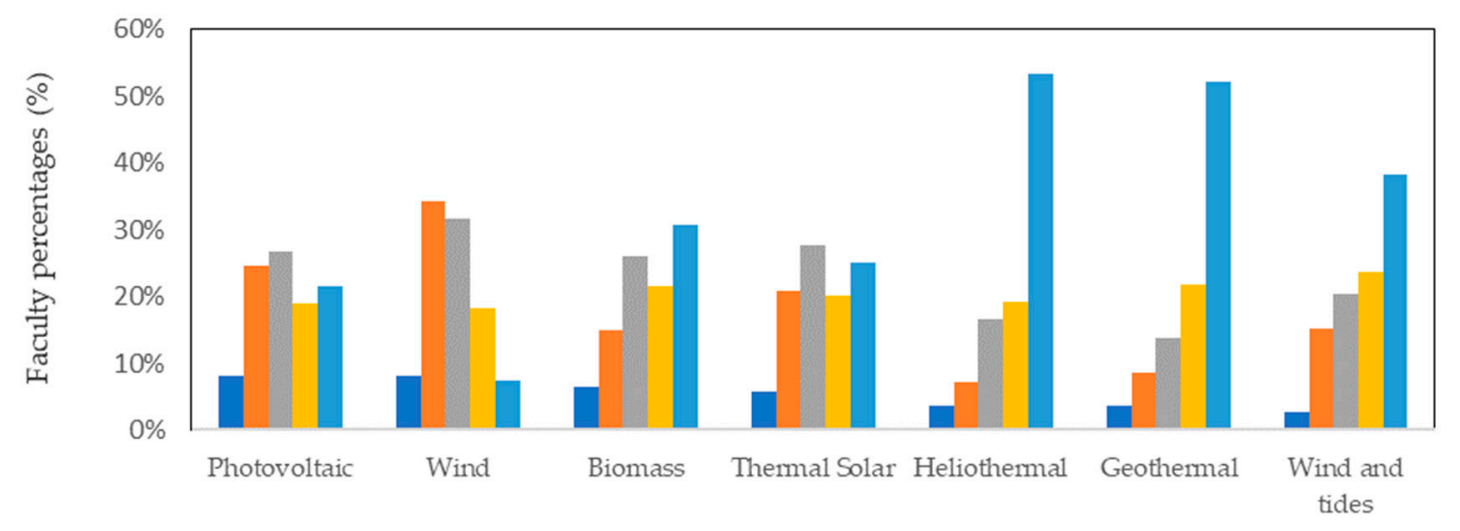

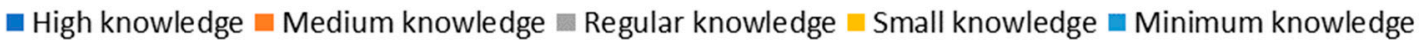

Figure 3. Level of knowledge declared by the total number of teachers on different renewable energy sources. 


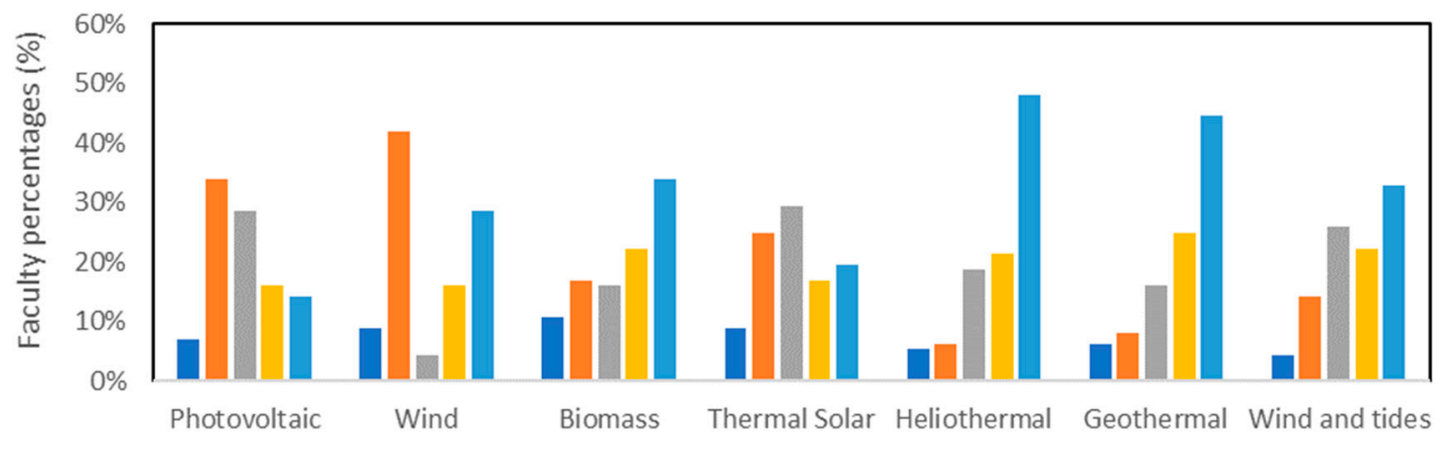

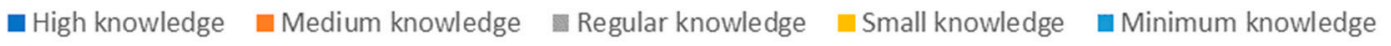

Figure 4. Level of knowledge declared by teachers acting in the natural sciences and mathematics areas on different renewable energy sources.

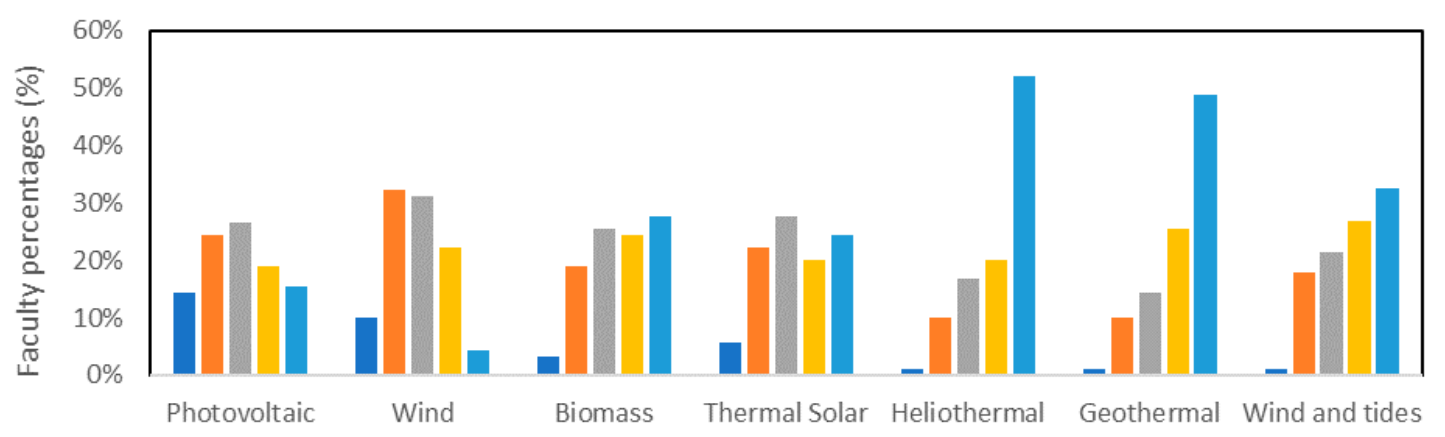

- High knowledge Medium knowledge $\quad$ Regular knowledge $\quad$ Small knowledge Minimum knowledge

Figure 5. Level of knowledge declared by teachers acting in the technological area on different renewable energy sources.

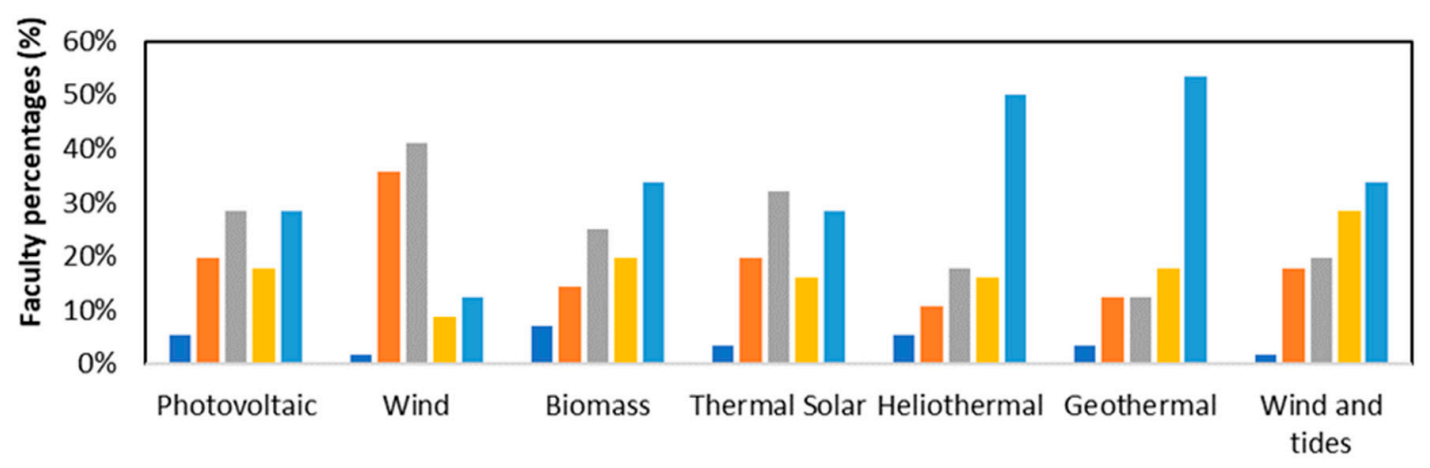

घigh knowledge $\square$ Medium knowledge $\square$ Regular knowledge $\square$ Small knowledge $\square$ Minimum knowledge

Figure 6. Level of knowledge declared by teachers acting in the humanities area on different renewable energy sources. 


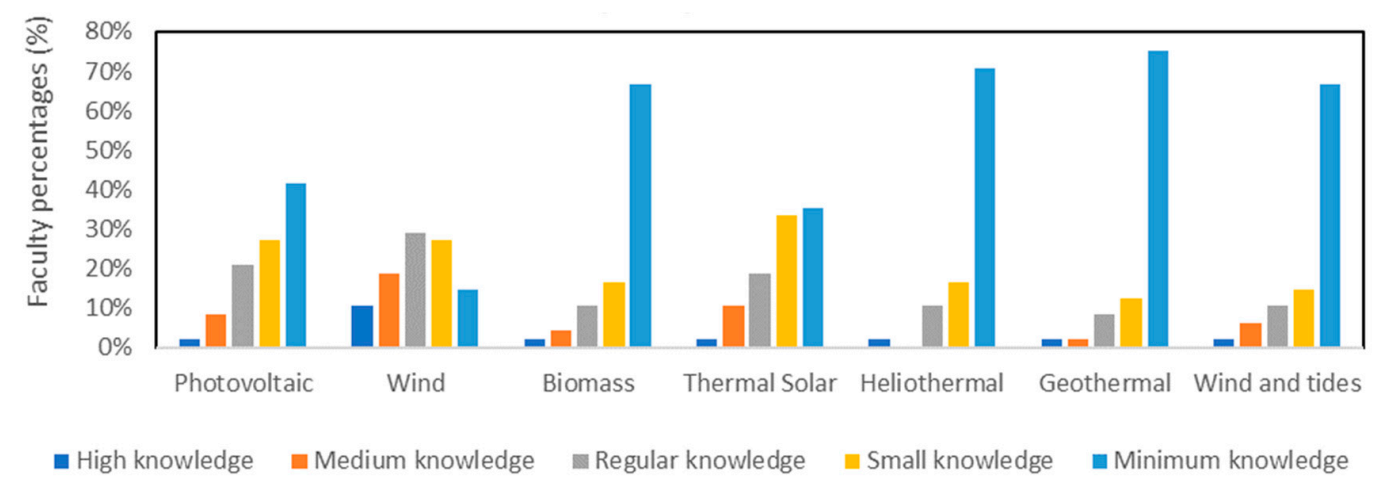

Figure 7. Level of knowledge declared by teachers acting in the language and codes area on different renewable energy sources.

The variables worked are qualitative because they present possible achievements or attributes of the researched individual and not possible realizations of numbers resulting from a count or measurement. Thus, the chi-square test can be applied because the research conditions fit this one since the groups of teachers by area of knowledge are independent. The significance level $\alpha$ (i.e., the risk of rejecting a true hypothesis) was established before data analysis and set at $5 \%(p=0.05)$.

By applying the chi-square test, it was verified the association of teaching groups by area, by the level of knowledge about renewable energy sources. It was observed that the group of language and code teachers $(p<0.05)$ showed statistically significant differences regarding their declared knowledge about renewable energies concerning the data obtained when these groups were grouped in one group (IFRN). The other groups $(p>0.05)$ did not present statistically significant differences in declared knowledge about renewable energy sources.

Regarding the analysis of the questionnaires answered by the teachers by knowledge area, it is evident the balanced distribution between the areas of natural sciences, mathematics and their technologies, and technological and human sciences and their technologies, since the chi-square test presented $(p>0.05)$. Teachers working in the natural sciences, mathematics, and technologies such as physics, chemistry, biology, and mathematics have their training and daily life in the classroom based on a greater ability to engage in knowledge related to renewable energy and sustainability, according to the contents covered in its activities. Humanities teachers also have the possibility to dialogue with renewable energy contents. Particularly for technology teachers, this possibility is much more evident, since knowledge about renewable energies can be presented in their curriculum for university education, as it happens with engineering teachers.

By the computed answers it was possible to verify that renewable energy as a pedagogical theme can encompass teachers from every field. Such scores could possibly not be due to the IFRN Solar Project, but they might be closely related to a global movement which since the 1970s has been successfully spreading the notion that renewable energy sources are a better conceptual alternative than centralized energy sources, like coal, oil derivates and nuclear energy. For Harjanne and Korhonen [32] the concept of renewable energy has become powerful and universal to the extent that it has been consensually included in global warming negotiations, and actions and appeals have significantly reached common citizens through global media.

\subsection{Teachers' Knowledge about Renewable Source}

The Common National Curriculum Base defined by Ministry of Education (MEC) [23] guides the curricula and orders the pedagogical proposals of the Federative Unit teaching systems and networks, thus establishing knowledge, skills and abilities that all students are expected to develop along their educational path. Curriculum insertion concerning the sustainable development theme occurs, explicitly, only in the natural sciences, pointing to the need for the following ability: To analyze and represent, with or without the use of specific digital devices and applications, the transformations and conservations in 
systems that involve the amount of matter, energy and movement to make predictions about their behaviors in everyday situations and production processes that prioritize sustainable development, the conscious use of natural resources and the preservation of life in all its forms [23].

Thus, it is understandable that teachers from different areas of knowledge express varying levels of knowledge on the subject, in some cases close to common sense. The omission of the theme in the curricula is also justified, considering that, with the exception of the curricular autonomy of educational institutions, their guidelines are based on the official MEC documents [23].

Table 3 indicates the source of teacher renewable energy knowledge. The data do not evidence teacher qualification and training provisions that may have occurred under the IFRN renewable energy framework. This is relevant, as this is an institution that formally claims to present a sustainable development policy and that develops projects and programs aimed at the rational use of energy and other sources of limited natural resources such as water, which at present is one of the biggest problems in the country, especially in the Brazilian northeast.

Table 3. Renewable energy teacher knowledge source.

\begin{tabular}{|c|c|c|}
\hline Knowledge Source & $\%$ & Teachers \\
\hline \multirow{5}{*}{$\begin{array}{l}\text { Personal interest through individual readings not } \\
\text { linked to daily school life. }\end{array}$} & 51 & General staff \\
\hline & 56 & Nature and Mathematics \\
\hline & 50 & Technological \\
\hline & 55 & Humanities \\
\hline & 33 & Languages and Codes \\
\hline \multirow{5}{*}{$\begin{array}{l}\text { Family socialization where I am presented } \\
\text { themes related to renewable energy. }\end{array}$} & 9.5 & General staff \\
\hline & 6.3 & Nature and Mathematics \\
\hline & 5.6 & Technological \\
\hline & 14 & Humanities \\
\hline & 19 & Languages and Codes \\
\hline \multirow{5}{*}{$\mathrm{TV}$, radio and magazine advertising. } & 36 & General staff \\
\hline & 32 & Nature and Mathematics \\
\hline & 32 & Technological \\
\hline & 39 & Humanities \\
\hline & 50 & Languages and Codes \\
\hline \multirow{5}{*}{$\begin{array}{l}\text { Daily school life through information exchange } \\
\text { with other teachers. }\end{array}$} & 52 & General staff \\
\hline & 59 & Nature and Mathematics \\
\hline & 43 & Technological \\
\hline & 52 & Humanities \\
\hline & 52 & Languages and Codes \\
\hline \multirow{5}{*}{$\begin{array}{l}\text { The presence of the theme related to renewable } \\
\text { energies in subject contents and } \\
\text { academic activities. }\end{array}$} & 43 & General staff \\
\hline & 56 & Nature and Mathematics \\
\hline & 42 & Technological \\
\hline & 38 & Humanities \\
\hline & 19 & Languages and Codes \\
\hline \multirow{5}{*}{ I have no knowledge on renewable energy. } & 1.9 & General staff \\
\hline & 0.9 & Nature and Mathematics \\
\hline & 2.2 & Technological \\
\hline & 0 & Humanities \\
\hline & 6.8 & Languages and Codes \\
\hline \multirow{5}{*}{ Other source. } & 2.0 & General staff \\
\hline & 2.7 & Nature and Mathematics \\
\hline & 3.3 & Technological \\
\hline & 8.9 & Humanities \\
\hline & 2.1 & Languages and Codes \\
\hline
\end{tabular}

Source: Prepared by the authors. 
These data indicate the need to integrate the necessary knowledge on issues involving renewable energy to teacher training. As stated by most interviewees, their knowledge of the subject is acquired through co-workers or other informal spaces, and this lack of scientific knowledge on the subject is unlikely to bring profound changes in attitude towards teachers and consequently, students. Therefore, the appropriation of knowledge related to renewable energies should not be restricted to knowledge elaborated, individually or collectively, by the teachers themselves in the reflection process about their practices, but also incorporate knowledge elaborated by the scientific community. The innovative aspect of this perspective is to provide concrete elements to raise the knowledge status produced by teachers in their experience, without restricting it to this kind of knowledge [33].

The appropriation of the knowledge necessary for the exercise of teaching results largely from initial teacher formation, since this is the moment that the future of the profession is projected and idealized. However, other types of knowledge that both teacher and school institution are responsible for is constructed during the professional exercise, according to the choices made in this area concerning curricula definition.

According to Gauthier [33] knowledge is, first and foremost, the result of social production. In this sense, it is much more than the result of the interaction between subjects or a linguistic interaction in a given context, and will only "have value insofar as it allows maintaining an open process of questioning. Thus, teacher knowledge is argumentative and social" [33]. As subjects situated in a specific context, which is prepared to achieve pedagogical objectives, teachers use unusual situations, make judgments and mobilize the knowledge necessary for their decision-making process.

Thus, by analyzing the various sources in which teachers claim to have acquired knowledge about renewable energies, one can reiterate, in the same line of thought as Tardif [34], that teacher relationship with knowledge is not strictly cognitive (i.e., that teachers are not limited to knowledge concerning their specific work area), but are mediated by knowledge from other sources, such as pedagogical knowledge and knowledge constructed throughout the experiences of each teacher in the profession. Therefore, in an education conception that goes beyond the boundaries of disciplinary knowledge, teachers require continuing education, which must be a shared responsibility with the institution, so that they can appropriate other knowledge as necessary as disciplinary knowledge. Thus, it is understood that teachers deal with both content and classroom management and, therefore, must resort to different knowledge, necessary to achieve the previously defined objectives, regarding student citizen formation.

\subsection{Knowledge on the existence of Photovoltaic Plants installed at IFRN Campuses}

This work investigated the teachers' knowledge about the existence of photovoltaic plants installed on IFRN campuses aiming to have the dimension of the presence of the IFRN Solar Project in daily teaching. It was first asked if they were aware of any renewable energy system installed in the city where they live or work. From an affirmative answer the interviewee was led to point out, among the listed technologies, which one was used in the installed system they knew. The available options would reveal to us the nature of such plants' property as well as their location: Private (industry, commerce, residence or other) or public (hospital, school, research institute or other). A total of $88.6 \%$ of the participants noted that they were aware of some renewable energy system plant.

It was expected that IFRN photovoltaic plants would be identified in this question, but when asked about the existence of any specific action focused on the use of renewable resource technologies at the IFRN campus where the interviewee acts, the existence of photovoltaic solar plants was identified by only $69 \%$ of all teachers; $27.8 \%$ in nature science, mathematics and their technologies (NSM), $22.2 \%$ in technology (TEC), $11.4 \%$ in humanities and technologies (HC) and $7.2 \%$ in languages, codes and technologies (LC).

When teachers' subject was accounted for, it is found that the knowledge of those in the technology field and of those in natural sciences and mathematics fields the percentages of knowledge was around $80 \%$. These values were expected and confirm that which had already been asserted in the Section 4.2, 
which notes that these teachers' familiarity with photovoltaic systems traces back to their training area and inherent competences and skills. Humanities and language teachers, on the other hand, expressed a lower percentage (66\% and 59\%, respectively) of awareness regarding the installation of photovoltaic plants in their work place.

The nature of this lack of knowledge lies in the already ingrained concept that separates technique and technology from the humanities, imposing a value that separates numbers from letters. This group of social sciences teachers has a high potential for disseminating the attitudes and values for the education for sustainability, since they can escape from document and subject constraints by making use of books, magazines, drama, social medias, among other resources on the sustainability topic.

\subsection{Photovoltaic Plants Installed at IFRN Campuses and Their Presence in the Teaching-Learning Process and Contributions to Sustainable Development}

As a way to enable the mapping of faculty's perceptions in relation to the repercussion of the installation of photovoltaic systems in their pedagogical practice, a set of questions was structured in order to identify the adherence of IFRN Solar Project's objectives to teachers' daily practice in terms of the dissemination of sustainability's conceptual bases and principles and their interaction with the curriculum and formal content on the surveyed campuses.

Tables 4 and 5 refer to the perception of the teaching staff about their pedagogical practice regarding the challenges of including the renewable energy theme in daily school life.

Table 4 shows that $41.7 \%$ of the teachers indicate that contents related to renewable energies are unsatisfactorily present in everyday school life. A high percentage of teachers $(27.8 \%)$ have no opinion on the issue. As a result, $25.4 \%$ of the general staff recognizes that they do not work on renewable energy content in their teaching practice. Surprisingly, $47 \%$ of these preferred not to give their opinion, revealing that the percentage of those who do not bring the renewable energy theme to the classroom is well above $25.4 \%$.

Asked if the actions conducted by IFRN are presented to students in their daily school life, mainly concerning the existence of photovoltaic plants, $29 \%$ of the general staff consider that these actions are unsatisfactory or are not present in classroom practice and/or academic activities. Again, a high percentage of teachers who prefer not to give their opinion $(44 \%)$ is noted.

Regarding the dissemination of the sustainable development concept among IFRN campuses, teaching staff opinions were as follows: $41 \%$ consider that this concept is worked in a very satisfactory or satisfactory way, while $33.1 \%$ indicate the opposite. Those who revealed no opinion consisted in $25.8 \%$ of the total.

It is important to highlight that the concept of sustainable development has occupied a privileged space in television, radio and newspapers, indicating that it is taken to daily school life through the exchange of information between teachers and students, without being included in a structured, formal and systemic manner in school practice, being more of a debate within the common sense instead of a pedagogical practice.

In addition, a high percentage of interviewees that gave no opinion can be assessed as indicative of the distance of the teaching staff with transversal themes to formal contents worked in the classroom. This lack of opinion is very much linked to the lack of knowledge about the object, as well as the practice of avoiding scandals and/or opinions that can be interpreted as a faculty or manager criticism.

The questions discussed in Table 4, when stratified by knowledge area, maintain the response percentages in the same range as those presented by the general teacher staff.

From the teachers' judgement it was possible to perceive here an important distancing from the objectives that justified the adoption of photovoltaic systems. The contents did not come to include the theme of sustainability, not even the ones linked to renewable sources. There is a clear sign that IFRN Solar Project actions are not being publicized to the students. These inferences show the importance of advancing the diagnosis and then designing actions under which the intervention capacity of public 
policies aimed at integrating the culture of sustainability to the implementation of photovoltaic solar systems on campuses can be enhanced.

Table 4. Teacher evaluations about the existence of a pedagogical practice that addresses contents regarding renewable energy sources in daily school life.

\begin{tabular}{|c|c|c|c|c|c|c|}
\hline & $\begin{array}{c}\text { Very } \\
\text { Satisfactory }\end{array}$ & Satisfactory & No Opinion & Unsatisfactory & $\begin{array}{l}\text { Not Present in } \\
\text { Academic Subjects } \\
\text { and/or Activities }\end{array}$ & $\begin{array}{c}\text { IFRN } \\
\text { Faculty } \\
\text { Areas }\end{array}$ \\
\hline & \multicolumn{6}{|c|}{ Percentages (\%) } \\
\hline \multirow{5}{*}{$\begin{array}{l}\text { The contents linked } \\
\text { to renewable energy } \\
\text { (RE) are present in } \\
\text { everyday school life }\end{array}$} & 2.4 & 24.7 & 27.8 & 41.7 & 3.4 & General staff \\
\hline & 2.8 & 30.8 & 16.8 & 47.7 & 1.9 & $\begin{array}{l}\text { Nature and } \\
\text { Mathematics }\end{array}$ \\
\hline & 2.3 & 21.8 & 28.7 & 40.2 & 6.9 & Technological \\
\hline & 3.6 & 23.6 & 34.5 & 36.4 & 1.8 & Humanities \\
\hline & 0.0 & 17.4 & 43.5 & 37.0 & 2.2 & $\begin{array}{l}\text { Languages } \\
\text { and Codes }\end{array}$ \\
\hline \multirow{5}{*}{$\begin{array}{l}\text { Teachers work with } \\
\text { RE content }\end{array}$} & 1.7 & 24.7 & 45.4 & 25.4 & 2.7 & General staff \\
\hline & 1.9 & 29.9 & 38.3 & 29.0 & 1.0 & $\begin{array}{l}\text { Nature and } \\
\text { Mathematics }\end{array}$ \\
\hline & 1.1 & 20.7 & 47.1 & 26.4 & 4.6 & Technological \\
\hline & 1.8 & 27.3 & 31.0 & 36.4 & 3.6 & Humanities \\
\hline & 2.2 & 17.4 & 54.3 & 23.9 & 2.2 & $\begin{array}{l}\text { Languages } \\
\text { and Codes }\end{array}$ \\
\hline \multirow{5}{*}{$\begin{array}{l}\text { Actions conducted } \\
\text { by IFRN on RE are } \\
\text { taken to students }\end{array}$} & 2.7 & 23.7 & 44.4 & 27.5 & 1.7 & General staff \\
\hline & 3.7 & 26.2 & 36.4 & 25.2 & 8.4 & $\begin{array}{l}\text { Nature and } \\
\text { Mathematics }\end{array}$ \\
\hline & 2.3 & 19.5 & 46.0 & 27.6 & 4.6 & Technological \\
\hline & 0.0 & 20.0 & 52.7 & 27.3 & 0.0 & Humanities \\
\hline & 4.3 & 15.2 & 50.0 & 30.5 & 0.0 & $\begin{array}{l}\text { Languages } \\
\text { and Codes }\end{array}$ \\
\hline \multirow{5}{*}{$\begin{array}{l}\text { The concept of } \\
\text { sustainable } \\
\text { development (SD) is } \\
\text { worked on campus }\end{array}$} & 7.1 & 33.9 & 25.8 & 32.2 & 1.0 & General staff \\
\hline & 3.7 & 34.6 & 27.1 & 33.6 & 1.0 & $\begin{array}{l}\text { Nature and } \\
\text { Mathematics }\end{array}$ \\
\hline & 12.6 & 39.1 & 23.0 & 23.0 & 2.3 & Technological \\
\hline & 3.6 & 38.2 & 23.6 & 34.6 & 0.0 & Humanities \\
\hline & 8.7 & 17.4 & 30.9 & 43.5 & 0.0 & $\begin{array}{l}\text { Languages } \\
\text { and Codes }\end{array}$ \\
\hline
\end{tabular}

Source: Prepared by the authors.

Table 5 shows the teachers' assessment of their own practice and identifies barriers and opportunities that favor or block possible pedagogical practices and actions aimed at improving their qualification and performance in an environment oriented to the promotion and dissemination of sustainability. This table was developed from the "statements" presented to the teachers so that they could express their agreement or disagreement in a staggered manner. These statements aim to evaluate what teachers consider to be mandatory to insert in the curricular contents related to renewable sources of energy (considering the existence of photovoltaic generation units in the campuses where they work) and consequently, to assess some elements that might contribute to the improvement and effectiveness of IFRN Solar Project with regard to promoting sustainability.

Table 5 shows "statements" presented to teachers so that they would express their agreement or disagreement in a scored manner. These statements aim to evaluate what teachers consider as imperative concerning the insertion of contents related to renewable sources of energy in daily school life, considering the existence of photovoltaic units in their campuses, and consequently, their assessment of assess elements that may contribute to the improvement and effectiveness of the IFRN Solar Project with regard to promoting sustainability. 
In general, teachers were classified according to the knowledge domain that enables them to address topics related to renewable energy in the classroom, where $44 \%$ strongly agreed or agreed to present such capacity, 39\% strongly disagreed or disagreed and $17 \%$ gave no opinion. Teachers were less educated in addressing the subject in the codes and languages area, where $68 \%$ strongly disagreed or disagreed concerning knowledge that enables them to include the subject in their activities.

Even divided according to their skills and competence to bring the renewable energy subject to a pedagogical practice, $94 \%$ of the general staff expressed an interest in learning more about the subject and $84 \%$ agreed that a training program would make it possible to supply such a demand. The same levels were observed when evaluating this question by knowledge area.

The development of didactic material related to renewable energy, as well as a greater promotion of the theme in the various campuses counts with the agreement of $90 \%$ of general faculty. When assessed by knowledge area this question had the same level of acceptance.

The official inclusion, in an interdisciplinary manner, of renewable energy content in the curriculum was advocated by $73 \%$ of the general staff, maintained when assessing the issue by area of education. It is noteworthy that the teaching staff, both general and by knowledge area, rejected the idea that this curriculum inclusion should be limited to technical and higher technological courses.

It is important to highlight that only $11.2 \%$ of the teachers considered that the knowledge area they act in has no link to contents related to renewable energy. This perception rose when an assessment was carried out by knowledge area, by $18 \%$ for human sciences teachers and $26 \%$ for language and codes teachers.

When asked about promoting awareness of the role of energy in people's lives and in society, $87 \%$ of the overall staff agreed that this should be one of the school's tasks. The same levels were observed when evaluating this question by knowledge area.

The high workload in the classroom associated with other academic activities was presented by $47 \%$ of the general staff as a barrier to the introduction of themes related to renewable sources in the school practice, maintained when evaluating this question by knowledge area.

Table 5. Teaching assessment on how much teacher knowledge and demands required for content insertion regarding renewable energy sources in daily school life.

\begin{tabular}{|c|c|c|c|c|c|c|}
\hline & \multicolumn{6}{|c|}{ Percentages (\%) } \\
\hline & $\begin{array}{l}\text { Totally } \\
\text { Agree }\end{array}$ & Agree & No Opinion & Disagree & $\begin{array}{c}\text { Totally } \\
\text { Disagree }\end{array}$ & IFRN Faculty Areas \\
\hline \multirow{5}{*}{$\begin{array}{l}\text { The level of knowledge I have } \\
\text { about RE enables me to include } \\
\text { related topics in my } \\
\text { classroom activities. }\end{array}$} & 9.8 & 34.6 & 17.0 & 29.5 & 9.2 & General staff \\
\hline & 11.2 & 41.1 & 13.1 & 26.2 & 8.4 & $\begin{array}{l}\text { Nature and } \\
\text { Mathematics }\end{array}$ \\
\hline & 9.2 & 34.5 & 20.7 & 28.7 & 6.9 & Technological \\
\hline & 10.9 & 36.4 & 21.8 & 23.6 & 7.3 & Humanities \\
\hline & 6.5 & 17.4 & 13.0 & 45.7 & 17.4 & Languages and Codes \\
\hline \multirow{5}{*}{$\begin{array}{l}\text { A training program is required } \\
\text { so that I can broaden my } \\
\text { knowledge and develop my } \\
\text { skills in teaching RE aspects. }\end{array}$} & 32.2 & 51.9 & 11.9 & 4.8 & 0.0 & General staff \\
\hline & 26.2 & 59.8 & 8.4 & 5.6 & 0.0 & $\begin{array}{l}\text { Nature and } \\
\text { Mathematics }\end{array}$ \\
\hline & 37.9 & 47.1 & 12.6 & 2.3 & 0.0 & Technological \\
\hline & 38.2 & 41.8 & 10.9 & 9.1 & 0.0 & Humanities \\
\hline & 28.3 & 54.4 & 15.2 & 2.2 & 0.0 & Languages and Codes \\
\hline \multirow{5}{*}{$\begin{array}{l}\text { I would like to learn more } \\
\text { about RE. }\end{array}$} & 34.6 & 58.6 & 5.4 & 1.4 & 0.0 & General staff \\
\hline & 36.4 & 53.3 & 8.4 & 1.9 & 0.0 & $\begin{array}{l}\text { Nature and } \\
\text { Mathematics }\end{array}$ \\
\hline & 34.5 & 62.1 & 3.5 & 0.0 & 0.0 & Technological \\
\hline & 38.2 & 54.6 & 3.6 & 3.6 & 0.0 & Humanities \\
\hline & 30.4 & 65.2 & 4.3 & 0.0 & 0.0 & Languages and Codes \\
\hline
\end{tabular}


Table 5. Cont.

\begin{tabular}{|c|c|c|c|c|c|c|}
\hline & \multicolumn{6}{|c|}{ Percentages (\%) } \\
\hline & $\begin{array}{l}\text { Totally } \\
\text { Agree }\end{array}$ & Agree & No Opinion & Disagree & $\begin{array}{c}\text { Totally } \\
\text { Disagree }\end{array}$ & IFRN Faculty Areas \\
\hline \multirow{5}{*}{$\begin{array}{l}\text { It is necessary to develop } \\
\text { educational material related to } \\
\text { RE that can account for the } \\
\text { interdisciplinary character } \\
\text { present in this type of content. }\end{array}$} & 32.9 & 56.3 & 9.4 & 1.7 & 0.0 & General staff \\
\hline & 32.7 & 57.0 & 8.4 & 1.9 & 0.0 & $\begin{array}{l}\text { Nature and } \\
\text { Mathematics }\end{array}$ \\
\hline & 26.4 & 60.9 & 11.5 & 1.1 & 0.0 & Technological \\
\hline & 41.8 & 45.9 & 10.9 & 1.8 & 0.0 & Humanities \\
\hline & 26.1 & 69.6 & 4.3 & 0.0 & 0.0 & Languages and Codes \\
\hline \multirow{5}{*}{$\begin{array}{l}\text { IFRN needs to further promote } \\
\text { the RE theme on campus. }\end{array}$} & 32.2 & 56.3 & 8.8 & 2.7 & 0.0 & General staff \\
\hline & 32.7 & 56.1 & 6.5 & 4.7 & 0.0 & $\begin{array}{l}\text { Nature and } \\
\text { Mathematics }\end{array}$ \\
\hline & 28.7 & 54.0 & 15.0 & 2.3 & 0.0 & Technological \\
\hline & 38.9 & 52.7 & 7.3 & 1.8 & 0.0 & Humanities \\
\hline & 30.4 & 65.2 & 4.3 & 0.0 & 0.0 & Languages and Codes \\
\hline \multirow{5}{*}{$\begin{array}{l}\text { My workload and other } \\
\text { academic activities do not } \\
\text { allow me time to teach content } \\
\text { outside of what is formally } \\
\text { required in the curriculum. }\end{array}$} & 15.9 & 31.2 & 16.3 & 36.6 & 0.0 & General staff \\
\hline & 14.0 & 33.6 & 15.9 & 36.5 & 0.0 & $\begin{array}{l}\text { Nature and } \\
\text { Mathematics }\end{array}$ \\
\hline & 13.8 & 33.3 & 16.1 & 36.8 & 0.0 & Technological \\
\hline & 20.0 & 25.9 & 16.4 & 38.2 & 0.0 & Humanities \\
\hline & 19.6 & 28.3 & 17.4 & 34.9 & 0.0 & Languages and Codes \\
\hline \multirow{5}{*}{$\begin{array}{l}\text { RE content should be officially } \\
\text { introduced into the curriculum } \\
\text { in an interdisciplinary manner. }\end{array}$} & 20.0 & 52.9 & 19.0 & 8.1 & 0.0 & General staff \\
\hline & 19.6 & 56.1 & 17.8 & 6.6 & 0.0 & $\begin{array}{l}\text { Nature and } \\
\text { Mathematics }\end{array}$ \\
\hline & 16.1 & 50.6 & 25.3 & 8.1 & 0.0 & Technological \\
\hline & 23.6 & 50.9 & 14.6 & 10.9 & 0.0 & Humanities \\
\hline & 23.9 & 52.2 & 15.2 & 8.7 & 0.0 & Languages and Codes \\
\hline \multirow{5}{*}{$\begin{array}{l}\text { The issue of awareness about } \\
\text { the role of energy in people's } \\
\text { lives and society should be the } \\
\text { parents' responsibility, } \\
\text { not the schools. }\end{array}$} & 1.0 & 6.1 & 5.4 & 56.6 & 30.3 & General staff \\
\hline & 0.0 & 2.8 & 5.6 & 61.7 & 29.9 & $\begin{array}{l}\text { Nature and } \\
\text { Mathematics }\end{array}$ \\
\hline & 1.1 & 8.0 & 10.3 & 51.7 & 28.8 & Technological \\
\hline & 1.8 & 10.9 & 0.0 & 54.6 & 32.7 & Humanities \\
\hline & 2.2 & 4.3 & 2.2 & 56.5 & 34.8 & Languages and Codes \\
\hline \multirow{5}{*}{$\begin{array}{l}\text { I do not see a need to include } \\
\text { RE-related content in school } \\
\text { curriculum, except in the case } \\
\text { of technical and higher } \\
\text { technological courses. }\end{array}$} & 0.3 & 5.1 & 7.8 & 58.6 & 28.1 & General staff \\
\hline & 0.0 & 2.8 & 8.4 & 61.7 & 27.1 & $\begin{array}{c}\text { Nature and } \\
\text { Mathematics }\end{array}$ \\
\hline & 1.1 & 6.9 & 9.2 & 55.2 & 27.6 & Technological \\
\hline & 0.0 & 7.3 & 7.3 & 56.4 & 29.1 & Humanities \\
\hline & 0.00 & 4.34 & 4.34 & 60.9 & 30.5 & Languages and Codes \\
\hline \multirow{5}{*}{$\begin{array}{l}\text { The area of knowledge that I } \\
\text { work in has no link with } \\
\text { RE-related contents. }\end{array}$} & 2.0 & 9.8 & 6.8 & 45.1 & 36.3 & General staff \\
\hline & 0.0 & 3.7 & 1.9 & 51.4 & 43.0 & $\begin{array}{l}\text { Nature and } \\
\text { Mathematics }\end{array}$ \\
\hline & 1.1 & 9.2 & 12.6 & 40.2 & 36.8 & Technological \\
\hline & 3.6 & 14.6 & 3.6 & 40.0 & 38.2 & Humanities \\
\hline & 6.5 & 19.6 & 10.9 & 45.7 & 17.4 & Languages and Codes \\
\hline
\end{tabular}

Source: Prepared by the authors.

\section{Conclusions}

Globally, fossil energy sources account for about $75 \%$ of $\mathrm{CO}_{2}$ emissions. Maintaining the current energy production and use structure jeopardizes the achievement of the climate conference goals of keeping the average earth temperature below $2{ }^{\circ} \mathrm{C}$ above pre-industrial levels. Therefore, national states make efforts to promote and integrate renewable sources into their strategic development plans and programs based on the promotion of sustainability. Notably, photovoltaic solar energy and wind energy have been widely stimulated in publicizing their benefits to Greenhouse Gases (GHG) mitigation and their contributions to sustainability, aiming at a better understanding and, consequently, its social acceptance. 
In this context, educational institutions have the potential to play an important role in the incorporation of renewable energy knowledge and skills, including their contents in teaching, research and extension curricula and/or activities, thus spreading the sustainability culture by appropriating the student framework concerning the knowledge and skills that lead them to understand the importance of renewable sources and incorporate them in their daily lives.

This article investigates the public policy conducted by the Brazilian government aimed at promoting the installation of photovoltaic solar systems in 644 teaching units of the Federal Network, regarding its objective of bringing to the educational space and the pedagogical practice the benefits of the adoption of photovoltaic solar energy to sustainability. A questionnaire was used to obtain information that unveiled the knowledge, practice and links given by teachers regarding the contents and values that can be extracted from the presence of photovoltaic generation units in IFRN campuses. This allowed for the assessment that the objective of disseminating sustainability assumptions in the teaching-learning space was not satisfactorily achieved. In general, teachers are knowledgeable about the role of renewable sources, but this knowledge is mostly obtained through personal interest, without links to their school practice.

Thus, the necessary connections to promote sustainability from the existence of photovoltaic units in IFRN campuses were insufficient, and do not in themselves favor the consolidation of the concept and the adoption of pedagogical practices that materialize this in school practice. The results indicate that a training program is necessary in order to expand teaching staff knowledge and develop their skills regarding renewable energies and their contributions to sustainability. The inability of teachers to bring knowledge related to renewable energies to the classroom and link them to social and daily school life these contents must be included in the school curriculum.

Adopting renewable energy generation systems and, through them, promoting a sustainability culture in the school environment demands the development of teacher knowledge and attitudes related to the subject. Sustainability-oriented training should be present from initial teacher education and be followed by updates that can address the debate on environmental issues and the role of energy generation and use in society. In addition, this training must be continuous.

It is essential that content related to renewable energies be formally inserted in the curriculum and that didactic material be developed in an interdisciplinary way. In addition to the content, it is also important to state that the educational purposes of the school institution should go beyond the boundaries of instruction, as it also includes the responsibility for the formation of citizens that are socially responsible for their habitat and for life in society, which includes sustainable development promotion.

The article advances knowledge by discussing the validity of the supposed consensus on a direct link between the expansion of renewable energy sources and the guarantee that this automatically promotes sustainability. Therefore, there is a need for structuring a solid research network oriented to evaluate, plan and promote interventions that potentiate the positive impacts of the insertion of photovoltaic solar systems in educational practice beyond the limits of educational institutions, mitigating their negative externalities.

Otherwise, in a global environment of increasing environmental damage and uncertainties about stabilizing planetary $\mathrm{CO}_{2}$ emissions, the present generation may be indulging in a luxury that it cannot afford, wasting the opportunity to advance knowledge of the benefits, challenges and viability. These sources and technologies contribute, in principle, to a better balance between the dilemma of meeting human needs on a planet of limited resources, permeated by habits of wasteful consumption, and supported by large asymmetries in energy access.

The obtained results confine the research to the markedly social determinants: the teacher as actor and evaluator of the rebounds of the implemented project. However, it is considered necessary to expand this scope in new studies, so that the environmental developments and GHG emissions can be addressed in an integrated manner, as well as the economic rebounds of the research object developed in the article. The importance of taking the opportunity to advance the understanding of the benefits, 
challenges and economic viability of these sources and technologies is even greater given the global scenario of increasing environmental damage and uncertainties regarding the stabilization of planetary $\mathrm{CO}_{2}$ emissions.

It is important that the school education path is established in a way that makes students aware of the consequences of their choices in relation to the use of natural resources. In these terms, the interdisciplinary way of approaching knowledge of energy sources, uses and impacts contributes to improve pedagogical practices in order to promote sustainability. Such knowledge must be based on a practice between teachers and students that aim to exercise techniques that promote efficiency, waste reduction and knowledge of renewable energy sources.

Author Contributions: Conceptualization, M.F.F., M.A.V.F., N.F.d.S., A.F.d.S., and L.R.L.d.P.; data curation, M.F.F.; methodology, M.F.F., N.F.d.S., A.F.d.S., and L.R.L.d.P.; supervision, M.F.F., M.A.V.F., and N.F.d.S.; writing-original draft, M.F.F., N.F.d.S., A.F.d.S., and L.R.L.d.P.; writing-review \& editing, M.F.F., M.A.V.F., N.F.d.S., A.F.d.S., and L.R.L.d.P. All authors have read and agreed to the published version of the manuscript.

Funding: This work was supported by the Brazilian Higher Education Support Program-CAPES-and the Brazilian Ministry of Education.

Conflicts of Interest: The authors declare no conflict of interest. The funders had no role in the design of the study; in the collection, analyses, or interpretation of data; in the writing of the manuscript, and in the decision to publish the results.

\section{References}

1. UNEP-United Nations Environment Programme. Knowledge for Change. Available online: http://wedocs.unep.org/bitstream/handle/20.500.11822/7476/-UNEP\%202006\%20Annual\%20Report2007755.pdf?sequence=5\&isAllowed $=y$ (accessed on 4 April 2019).

2. López-Alcarria, A.; Olivares-Vicente, A.; Poza-Vilches, F. A Systematic Review of the Use of Agile Methodologies in Education to Foster Sustainability Competencies. Sustainability 2019, 11, 2915. [CrossRef]

3. MMA-Ministry of Environment. Agenda 21. Available online: http://www.mma.gov.br/responsabilidadesocioambiental/agenda-21 (accessed on 4 April 2019).

4. Góes, H.C.A. Análise Comparativa de Instrumentos para Avaliação da Sustentabilidade em Universidades Visando uma Proposta para o Brasil. Ph.D. Thesis, Universidade Federal do Rio de Janeiro, Programa de Planejamento Energético, PPE/COPPE/UFRJ, Rio de Janeiro, Brazil, 2015.

5. Freire, P. Pedagogia da Autonomia-Saberes Necessários à Prática Educativa, 31st ed.; Paz e Terra: São Paulo, Brazil, 1996; ISBN 8521902433.

6. Silva, P.D.; Mendes, F.A.; Nascimento, V.S. Paulo Freire e Sustentabilidade: Educação para a sociedade sustentável resultados e discussão. In Proceedings of the XVI Semana de Iniciação Científica e II Semana de Extensão, Crato, Brazil, 21-26 October 2013.

7. Góes, H.C.A.; Magrini, A. Higher education institution sustainability assessment tools: Considerations on their use in Brazil. Int. J. Sustain. High. Educ. 2016, 17, 322-341. [CrossRef]

8. Das Silva, M.G. Capitalismo Contemporâneo e "Questão Ambiental": O Desenvolvimento Sustentável e a Ação do Serviço Social. Ph.D. Thesis, Universidade Federal de Pernambuco, Programa de Pós-Graduação em Serviço Social PSS/UFPE, Recife, Brazil, 2008.

9. Sachs, I. Desenvolvimento: Includente, Sustentável, Sustentado, 1st ed.; Garamond: Rio de Janeiro, Brazil, 2004; ISBN 9788576170402.

10. Filho, W.L.; Manolas, E.; Pace, P. The future we want key issues on sustainable development in higher education after Rio and the un decade of education for sustainable development. Int. J. Sustain. High. Educ. 2015, 16, 112-129. [CrossRef]

11. Wiek, A.; Withycombe, L.; Redman, C.L. Key competencies in sustainability: A reference framework for academic program development. Sustain. Sci. 2011, 6, 203-218. [CrossRef]

12. Morin, E. A Religação dos Saberes, 2nd ed.; Bertrand: Rio de Janeiro, Brazil, 1998; ISBN 8528608417.

13. Suh, H.; Han, S. Promoting Sustainability in University Classrooms Using a STEM Project with Mathematical Modeling. Sustainability 2019, 11, 3080. [CrossRef]

14. Robert, K.W.; Parris, T.M.; Leiserowitz, A.A. What is Sustainable Development? Goals, Indicators, Values, and Practice. Environ. Sci. Policy Sustain. Dev. 2012, 47, 8-21. [CrossRef] 
15. Leicht, A.; Heiss, J.; Byun, W.J. Issues and Trends in Education for Sustainable Development; UNESCO, Digital Library: Paris, France, 2018; ISBN 9789231002441.

16. Grandisoli, E.A. Projeto Educação para a Sustentabilidade: Transformando Espaços e Pessoas. Uma Experiência de Sete Anos no Ensino Médio. Ph.D. Thesis, Universidade de São Paulo, Instituto de Energia e Ambiente, IEA/USP, São Paulo, Brazil, 2018.

17. MEC-Ministry of Education Thematic Committee on Vocational Training in Renewable Energy and Energy Efficiency. Available online: http://portal.mec.gov.br/ultimas-noticias/209-564834057/45681-comite-debateoferta-de-cursos-na-area-de-energia-renovavel (accessed on 5 June 2019).

18. IFSULDEMINAS-South of Minas Federal Institute of Education, Science and Technology: IF Solar Project. Available online: https://portal.ifsuldeminas.edu.br/index.php/ultimas-noticias-ifsuldeminas/78-noticias-daprodi/1008-if-solar (accessed on 6 June 2019).

19. IFRN-Rio Grande do Norte Federal Institute of Education, Science and Technology. United Public Administration System/IFRN—SUAP-IFRN. Available online: https://suap.ifrn.edu.br (accessed on 5 April 2018).

20. ANEEL_Brazilian Electricity Regulatory Agency ANEEL-2012. Available online: http://biblioteca.aneel.gov. br (accessed on 5 June 2019).

21. IFRN-Rio Grande do Norte Federal Institute of Education, Science and Technology: IFRN Solar Project. Available online: http://portal.ifrn.edu.br/campus/natalcentral/observatorio-da-energia (accessed on 5 June 2019).

22. Constantino, G.; Freitas, M.; Fidelis, N.; Pereira, M.G. Adoption of photovoltaic systems along a sure path: A life-cycle assessment (LCA) study applied to the analysis of GHG emission impacts. Energies 2018, 11, 2806. [CrossRef]

23. MEC - Ministry of Education: Common National Curriculum Base. Available online: http://basenacionalcomum. mec.gov.br/images/BNCC_EI_EF_110518_versaofinal_site.pdf (accessed on 27 November 2019).

24. Poder, S.H. Potentials and Challenges of Facade Mounted PV in Urban Areas-with Copenhagen International School as Case. Master's Thesis, Technical University of Denmark/Department of Electrical Engineering Centre for Electric Power and Energy (CEE), Copenhagen, Denmark, 2018.

25. Provdanov, C.C.; Freitas, E.C. Metodologia do Trabalho Científico: Métodos e Técnicas da Pesquisa e do Trabalho Acadêmico, 2nd ed.; Feevale: Novo Hamburgo, Brazil, 2013; ISBN 9788577171583.

26. Vilelas, J.C. Investigação—O Processo de Construção do Conhecimento, 1st ed.; Sílabo: Lisboa, Portugal, 2009; pp. 287-288. ISBN 9789726185574.

27. Morgado, J.C. O Estudo de Caso na Investigação em Educação, 1st ed.; De Facto: Santo Tirso, Portugal, 2013; ISBN 9789898557100.

28. Lohr, S.L.; Grove, P.; Belmont, A. Sampling: Design and Analysis, 2nd ed; QPßAn International Thomson Publishing Company: New York, NY, USA, 2000; ISBN 9780429296284.

29. Lakatos, E.M.; Marconi, E.M. Fundamentos de Metodologia Científica, 7th ed.; Atlas: São Paulo, Brazil, 2017; ISBN 978859711838.

30. Zyadin, A.; Puhakka, A.; Ahponen, P.; Pelkonen, P. Secondary school teachers' knowledge, perceptions, and attitudes toward renewable energy in Jordan. Renew. Energy 2014, 62, 341-348. [CrossRef]

31. Borg, C.; Gericke, N.; Höglund, H.O.; Bergman, E. The barriers encountered by teachers implementing education for sustainable development: Discipline bound differences and teaching traditions. Res. Sci. Technol. Educ. 2012, 30, 185-207. [CrossRef]

32. Harjanne, A.; Korhonen, J.M. Abandoning the concept of renewable energy. Energy Policy 2019, 127, 330-340. [CrossRef]

33. Gauthier, C.; Stéphane, M.; Jean-François, D. Por uma Teoria da Pedagogia-Pesquisas Contemporâneas Sobre o Saber Docente, 3rd ed.; Unijuí: Ijuí, Brazil, 2013; ISBN 978-85-419-0048-5.

34. Tardif, M. Saberes Docentes e Formação Profissional, 5th ed.; Vozes: Petrópolis, Brazil, 2005; ISBN 8532626688.

(C) 2020 by the authors. Licensee MDPI, Basel, Switzerland. This article is an open access article distributed under the terms and conditions of the Creative Commons Attribution (CC BY) license (http://creativecommons.org/licenses/by/4.0/). 